\title{
Branchecode: interne beheersing voor kleine ondernemingen
}

\section{Shari van den Hout-Hooi, Gerard Roorda en Bart Kamp}

SAMENVATTING Naleving van wet- en regelgeving - zoals bijvoorbeeld op het gebied van arbo en milieu - is voor veel kleine ondernemingen moeilijk beheersbaar, omdat er intern onvoldoende tijd, geld en deskundigheid is om de veelheid en complexiteit van deze regelingen up-to-date te houden. Het belang van naleving is echter even groot als bij grotere ondernemingen. Het Hoofdbedrijfschap Ambachten heeft daarom het instrument 'Branchecode' ontwikkeld. Branchecode is een generieke aanpak voor het ontwerp- en implementatieproces van interne beheersing voor kleine ondernemingen, met specifieke uitwerkingen per branche. De aanpak is nadrukkelijk gericht op de cultuur van de kleine ondernemer die veelal terugschrikt voor nieuwerwetse hypes van externe consultants en extra administratieve lasten. Inmiddels is de Branchecode in meerdere branches met succes ingevoerd. De aanpak is tevens geschikt voor toepassing binnen andere sectoren met kleine ondernemingen.

\section{Inleiding}

Interne controle is voor kleine ondernemingen even belangrijk als voor grote ondernemingen. Ook kleine ondernemingen lopen risico's op het gebied van bijvoorbeeld milieu en arbo. Kleine ondernemingen kennen specifieke problemen om deze risico's te kunnen beheersen. Er is vaak onvoldoende tijd en kennis om de ontwikkelingen in de ingewikkelde wet- en

Drs. S.I.U. van den Hout-Hooi is verbonden aan het Hoofdbedrijfschap Ambachten als projectcoördinator en tevens betrokken bij de beleidsontwikkeling 'Branchecodepad'. Drs. G. Roorda is verbonden aan het Hoofdbedrijfschap Ambachten als hoofd van de afdeling Onderzoek \& Ontwikkeling. Dr. B. Kamp RA is verbonden aan BDO Accountants \& Adviseurs. regelgeving te volgen. Bovendien deinst een kleine ondernemer terug voor de veelal omvangrijke administratieve lasten die voortvloeien uit de aanpak die wordt aanbevolen voor grote ondernemingen om tot een internal control-systeem te komen. In kleine ondernemingen stuurt veelal de ondernemer zelf de bedrijfsprocessen aan, zonder formele vastleggingen. Onder andere door direct toezicht kan met dergelijke 'management controls' in principe een adequate interne beheersing worden bereikt, mits de ondernemer weet waar hij op moet letten. Juist bij ingewikkelde regelgeving is dit laatste vaak een probleem.

Ter ondersteuning van de interne controle bij kleine ondernemingen heeft het Hoofdbedrijfschap Ambachten (HBA) het Branchecodepad ontwikkeld. In onderling overleg binnen de bedrijfstak worden gecentraliseerd per branche de risico's in kaart gebracht en worden richtlijnen ter beheersing van die risico's vastgesteld (normalisatie). Dit geheel van richtlijnen wordt de Branchecode genoemd. De Branchecode wordt verwerkt in een checklist voor risico-inventarisatie en evaluatie. Deze richtlijnen kunnen vervolgens door de individuele ondernemers worden geïmplementeerd. Het resultaat van de checklistinventarisatie levert informatie over nog te implementeren richtlijnen en het formuleren van een Plan van Aanpak voor de implementatie hiervan.

Met het Branchecodepad is een hulpstructuur ontwikkeld die toeziet op zowel de informatiebehoefte van de ondernemer, als op de diverse eisen vanuit de samenleving. De Branchecode integreert de meest relevante terreinen van Maatschappelijk Verantwoord Ondernemen door kleine ambachtelijke bedrijven. Met de Branchecode start een normalisatieproces dat in een hanteerbare normenset resulteert, toegespitst op de specifieke bedrijfsvoering per ambachtelijke branche en typerende kenmerken en behoeften van het ambachtelijk midden- en kleinbedrijf (amkb). De Branchecode bevat alle normelementen die toezien 
op het beheersen van specifieke bedrijfsrisico's in het betreffende ambachtelijk bedrijf. Met de Branchecode heeft de ondernemer in het ambacht met minimale zoekkosten en minimale informatieverwerkingstijd een actuele en praktische informatiebron van alle wettelijke normen en brancherichtlijnen die op zijn bedrijfsvoering van toepassing zijn. Doordat de kosten van de Branchecode op brancheniveau worden gedragen, is er een duidelijke efficiencywinst.

In dit artikel wordt besproken hoe met het Branchecodepad de specifieke problemen rond internal control bij kleine ondernemingen kunnen worden opgelost. Daartoe zullen de kenmerken van het Branchecodepad worden besproken aan de hand van het stramien van internal control zoals dat is geformuleerd in het coso-rapport. Allereerst worden in paragraaf 2 de specifieke problemen van internal control bij kleine ondernemingen besproken. In paragraaf 3 wordt aangegeven hoe het Branchecodepad deze specifieke problemen oplost. In paragraaf 4 en 5 wordt nader ingegaan op de overwegingen om naleving van Branchecodes al of niet te certificeren, en de rol van de accountant. Tot slot zal in de laatste paragraaf worden ingegaan op de mogelijke toepassing van de Branchecodebenadering in andere mkb-sectoren.

\section{Internal control bij kleine ondernemingen}

$\mathrm{Al}$ enige jaren staat interne controle sterk in de belangstelling, mede ingegeven door het coso-rapport (coso, 1994). Interne beheersing (internal control) is een proces gericht op het verkrijgen van een redelijke mate van zekerheid omtrent het bereiken van de ondernemingsdoelstellingen. Om het bereiken van de ondernemingsdoelstellingen te waarborgen, is het noodzakelijk dat er een integraal systeem van interne controle wordt onderhouden. Inmiddels zijn er diverse 'producten' op het gebied van interne controle ontwikkeld, zoals het Analyse- en Beoordelingsinstrument Interne Beheersing (ABIB) van het Nivra. Ook het INK-model van het Instituut Nederlandse Kwaliteit biedt een structuur voor het verbeteren van de bedrijfsvoering. De internal control-discussie richt zich primair op de grotere ondernemingen. Vaak wordt zijdelings wel opgemerkt dat de principes van internal control eveneens van toepassing zijn op kleine ondernemingen, maar dat de uitwerking enigszins anders zal zijn. Op de verdere specifieke problemen bij implementatie bij kleine ondernemingen wordt veelal niet ingegaan, hoewel bijvoorbeeld Maijoor (1997) het belang van internal control voor kleinere ondernemingen benadrukt. In het coso-rapport wordt op verschillende plaatsen ingegaan op de toepassing van internal control in kleine ondernemingen. Belangrijkste verschillen met internal control in grotere ondernemingen is dat het proces minder geformaliseerd is. Door direct toezicht door de ondernemer en de korte communicatielijnen, hoeven procedures en sturingsinformatie niet per se schriftelijk te worden vastgelegd. Benadrukt wordt dat op basis van 'management controls' de interne beheersing even effectief kan zijn als bij grotere ondernemingen. Ook wordt in het coso-rapport opgemerkt dat kleine ondernemingen vaak geen gespecialiseerde afdelingen kennen. Het is aan de ondernemer om via externe bronnen voldoende kennis op te doen over bijvoorbeeld wet- en regelgeving.

In het coso-rapport is internal control gericht op drie dimensies:

- betrouwbare financiële verslaggeving;

- effectiviteit en efficiency van de bedrijfsprocessen;

- voldoen aan wet- en regelgeving.

Het coso-rapport stamt uit het vakgebied accountancy. Vandaar dat in de literatuur over internal control met name de eerste dimensie centraal staat. De twee andere dimensies liggen wat verder af van het vakgebied accountancy, al zijn ook hierbij duidelijk bedrijfseconomische aspecten te onderscheiden. Voor de continuïteit van de onderneming zijn deze twee dimensies niet minder wezenlijk dan betrouwbare financiële verslaggeving. Bedrijfsrisico's en ongevallen zijn gewoonlijk het meest evident bij grotere bedrijven, in bijvoorbeeld sectoren als de chemie, bouw en transport. Aan bedrijfsgerelateerde risico's en mogelijke gevolgen hiervan in het mkb wordt minder snel gedacht. Desalniettemin gaat het ook in het mkb om risico's met blijvende en vaak dramatische sociale en financiële gevolgen, zoals aangetoond door 'Enschede' en 'Volendam'. Berichten over incidenten in het MKB zijn zelden voorpaginanieuws, terwijl de ernst hiervan niet minder is. Ook de financiële gevolgen kunnen voor het kleinbedrijf schrijnend zijn, en zelfs een dreiging vormen voor de continuiteit. Over het algemeen heeft het grootbedrijf grotere (financiële) veerkracht bij het opvangen van investeringen en financiële claims als gevolg van bedrijfsongevallen. Voor een kleine ondernemer kan eenzelfde bedrijfsongeval het faillissement inleiden.

De wettelijke verantwoordelijkheid voor zaken als arbeidsomstandigheden en milieueffecten vraagt daarom om een systematische beheersing van bedrijfsrisico's. De systematiek van internal control is voor alledrie genoemde dimensies in principe hetzelfde. Voor elke dimensie geldt dat de volgende samenhangende elementen de internal control moeten waarborgen: 
- control environment;

- risico-analyse;

- interne controlemaatregelen;

- informatie \& communicatie;

- monitoring.

Om hieraan invulling te geven zijn gedegen kennis, kunde en instrumentaria bij bedrijven vereist. Voor het grootbedrijf geldt in het algemeen dat dergelijke specifieke kennis en kunde voorhanden is. Bij het kleinbedrijf is dit zeker geen vanzelfsprekendheid. Op grond van ervaringen met andersoortige borgingssytemen zoals ISO-certificering, is te verwachten dat bij de implementatie van internal control de volgende problemen zich zullen voordoen bij kleine ondernemingen:

- Korte planningshorizon: weinig bereidheid om langdurige investeringen in de organisatiestructuur door te voeren. Het uitstippelen van beleid op langere termijn is geen vanzelfsprekendheid, of geschiedt niet systematisch.

- 'Doe-cultuur': informele procedures, waaronder management controls, die daardoor moeilijk beheersbaar zijn. Nagenoeg alle functies worden noodgedwongen door de ondernemer zelf verricht. Hij investeert het merendeel van zijn tijd in de dagelijkse bedrijfsvoering.

- 'Baas in eigen bedriff': de ondernemer staat wantrouwend tegenover externe consultants (het 'not invited here syndrom'), en is eerder sterk gericht op vakidentiteit en -techniek.

- Weinig tijd om kennis te nemen van nieuwe ontwikkelingen buiten het directe vakgebied, daardoor ook weinig vaardigheid in selectie van informatie en de vertaling hiervan naar het eigen bedrijf. Andersom zal de informatievoorziening richting stakeholders óf minimaal, óf minder efficiënt gestroomlijnd plaatsvinden.

Samengevat kan worden afgeleid dat het zelfstandig implementeren van een integraal internal control-systeem per onderneming in het kleinbedrijf meestal niet mogelijk is, door gebrek aan kennis per onderneming en de hoge kosten om deze informatie in te kopen. Een internal control-systeem voor kleine ondernemingen heeft dus alleen kans van slagen indien voldaan is aan de volgende eisen:

- een geïntegreerde aanpak;

- eenvoudige en snelle implementatie;

- weinig administratieve lasten;

- aansluiting op de cultuur van de branche;

- relatief lage kosten.

De uitdaging om internal control-systemen voor kleine ondernemingen te ontwikkelen, is opgepakt door het HBA. Het HBA is een publiekrechtelijke bedrijfs- organisatie (PBO), ingesteld op grond van de Wet op de bedrijfsorganisatie. Het stelsel van publiekrechtelijke bedrijfsorganisaties (PBO's) is van oudsher de vorm van functionele decentralisatie van overheidswege. Een PBO opereert op het vlak van het algemeen maatschappelijk belang. De bestuursleden van het HBA worden voorgedragen door de representatieve werkgevers- en werknemersorganisaties. Het HBA is ingesteld voor de ambachtelijke sector. Het HBA staat voor de sociaal-economische ontwikkeling van de aangesloten ambachtelijke branches. Het werkterrein beslaat ruim 30 branches die tezamen zo'n 60.000 ondernemingen tellen. Deze branches variëren van heel klein, met twee bedrijven, tot zeer groot met meer dan 13.000 bedrijven. Ruim de helft van alle ambachtelijke bedrijven werkt zonder personeel. Slechts een enkel bedrijf heeft meer dan tien werknemers in dienst. Een belangrijke functie van het HBA is het creëren van passende randvoorwaarden voor een gezonde ontwikkeling van het amkb. Hiertoe worden zeker ook de wettelijke bepalingen die op een optimale bedrijfsvoering toezien gerekend.

\section{Het Branchecodepad}

Het Branchecodepad is gecreëerd door het HBA. Het centrale element in het Branchecodepad is de Branchecode. Kortgezegd is dit een op de specifieke branche toegesneden set van geïntegreerde richtlijnen voor risicobeheersing op alle relevante zorggebieden en bedrijfsvoeringaspecten. Het Branchecodepad kent drie fases: normalisatie, implementatie en certificering. Deze fases vormen de infrastructuur waarbinnen de Branchecode wordt ontwikkeld, geïmplementeerd en geborgd. Normalisatie staat voor het proces waarbij verschillende bij de branche betrokken stakeholders (onder andere de sociale partners, opleiding, leveranciers, Arbeidsinspectie, en Keuringsdienst van Waren) gezamenlijk de normen vaststellen waaraan de bedrijfsvoering moet voldoen. Figuur 1 (p. 370) geeft een voorbeeld van een pagina uit een Branchecode, de Code van de Voetverzorger. Vervolgens wordt in het implementatietraject de wijze waarop de normstelling kan worden behaald, gedefinieerd. Hierbij worden de te nemen maatregelen geconcretiseerd in een Plan van Aanpak. Op dit punt gaat het Branchecodepad verder dan bijvoorbeeld het INKmodel. Voor kleine ondernemingen ligt het gebruik van het INK-model vooral op de bewustwordingskant; het model wordt gebruikt om bijvoorbeeld de manier van samenwerken of de kennis van de markt tegen het licht te houden. Het uitvoeren van meer diepgaande diagnoses vanuit het INK-model komt 
vooral voor bij organisaties met een omvang van 30 medewerkers en meer ${ }^{1}$. Branchecode is duidelijk meer dan alleen bewustwording, en reikt concrete adviezen aan. De derde fase is de toetsing of het geïmplementeerde Plan van Aanpak daadwerkelijk wordt nageleefd. Bij het Branchecodepad hoort een trainingstraject op drie niveaus:

1 een trainingsmodule voor docenten in de initiële opleiding (docententraject);

2 een trainingsmodule voor trainers voor de bijscholing van zittende ondernemers (het 'train-the-trainertraject');

3 een trainingsmodule voor het bijscholingstraject voor zittende ondernemers (ondernemerstraject).

\section{Figuur 1. Voorbeeldpagina uit de Code van de Voetverzorger}

\section{Desinfecteren oppervlakken}

[D] Gebruik alléén geregistreerde desinfectiemiddelen (voorzien van een $\mathrm{N}$-nummer, met uitzondering van gedenatureerde alcohol 70-80\%) overeenkomstig hun wettelijk gebruiksvoorschrift.

Niet toegestaan voor desinfectie van instrumenten en oppervlakken zijn desinfectiemiddelen voorzien van een RVG-nummer (deze zijn bestemd voor wonddesinfectie).

Niet toegestaan voor desinfectie van instrumenten en oppervlakken zijn desinfectiemiddelen voorzien van een CE-markering (deze zijn bestemd voor medische hulpmiddelen)!

Gebruikte desinfectiemiddelen als gevaarlijk afval behandelen.

[1] Gebruik bij reinigen en desinfecteren persoonlijke beschermingsmiddelen (handschoenen).

Gebruik alcohol 70-80\% voor het desinfecteren van een oppervlak dat kleiner is dan $0,5 \mathrm{~m}^{2}$.

Gebruik chloortabletten volgens gebruiksvoorschrift (= dichloorisocyanuraat voorzien van $\mathrm{N}$-nummer) voor het desinfecteren van een oppervlak dat groter is dan $0,5 \mathrm{~m}^{2}$

5) Desinfecteer alléén oppervlakken die in aanraking (kunnen) zijn geweest met bloed of bloedbevattend materiaal, pus of beschadigde huid en voorkom dat chloortabletten voor routine-desinfectie gebruikt worden.

Reinigen en drogen gaat altijd vooraf aan desinfectie.

(5) Let op allergie en gebruiksdoel.

Desinfecteer volgens gebruiksaanwijzing, waarbij de contacttijd ten minste gelijk is aan de voor het desinfectiemiddel vastgestelde minimum inwerkingstijd (zie etiket) en neem de benodigde voorzorgsmaatregelen in acht.

Zorg tijdens reinigen en desinfecteren voor voldoende ventilatie.

Verklaring van symbolen in Figuur 1:

$\mathbb{1 0}]=$ wettelijk voorgeschreven of anderszins $d$ wingend

= gebruik in de branche c.q. stand der techniek/wetenschap

;:) = nastrevenswaardig
Het Branchecodepad is dus niet een statische, op zichzelf staande checklist, maar een integrale hulpstructuur van overlegprocessen en documentatie met iteratieve processen, waarbij het HBA een initiërende en coördinerende rol speelt. De breed opgezette infrastructuur van stakeholders en trainingstrajecten zijn cruciaal. Immers, het 'over de schutting gooien' van alleen een checklist heeft weinig kans van slagen. Naast de vakinhoudelijke kennis die in de Branchecode-checklist is opgenomen, zit de intelligentie van het instrument voor een zeer groot deel ook in de wijze waarop de drie fases van het Branchecodepad zijn georganiseerd.

Door de generieke opzet van deze structuur kan het Branchecodepad worden toegepast in allerlei verschillende bedrijfstakken. Na vaststelling van een Branchecode wordt deze met behulp van trainingstrajecten, regionale ondernemersbijeenkomsten, vakbladen, vakbeurzen, en schriftelijke voorlichting door het HBA en brancheorganisaties gelanceerd. Parallel aan het normalisatieproces vindt draagvlakcreatie plaats. Het blijkt dat de acceptatiegraad bij lancering relatief hoog is. De eerste persoonlijke mailing vanuit het HBA levert in het algemeen een respons van $12 \%$ op. Voor direct mailing is dit voor het HBA een hoge score. Het concept functioneert inmiddels in elf ambachtelijke branches. In 2001 zijn in zeven branches Branchecodeprojecten gestart. In 2002 hebben zich na kennisname van branchecodes inmiddels ook twee voorlopers uit de detailhandel gemeld. Tabel 1 geeft een indruk van de verankering van Branchecodes in het ambachtelijke mkb per december 2001.

Bij de uitwerking blijkt de Branchecode te voldoen aan de eisen die er aan gesteld mogen worden. De implementatie van de Branchecode is eenvoudig en veelal zonder vertaalslag door te voeren, doordat elke Branchecode specifiek is afgestemd op bedrijven in het betreffende ambacht. De omvang van de checklist is weliswaar niet beperkt, maar invulling levert dan ook goede managementinformatie op. De afstemming op de eigen bedrijfstak en de betrokkenheid van de sociale partners bij het vaststellen van elke Branchecode versterkt het draagvlak voor internal control. De Branchecode is als het ware eigendom van de branche, waarbij de brancheorganisaties en het HBA van oudsher vertrouwen genieten binnen het amkb. Het Branchecodepad fungeert zo als vorm van zelfregulering zoals de overheid beoogt met de MDW (Marktwerking, Deregulering en Wetgevingskwaliteit)-operatie.

De beperkte omvang en het trainingstraject maken het mogelijk om zonder veel extra administratieve lasten 
de onderneming te beheersen met behulp van de al bestaande praktijk van management controls. Door de Branchecode centraal te laten ontwerpen en onderhouden, worden de kosten van informatieverzameling gedeeld. De kosten van een Branchecodepad zijn derhalve relatief laag. De totale kosten voor een codetraject bij voldoende deelnemers uit een branche zijn ongeveer $€ 1500$ per bedrijf. De initiële out-of-pocketkosten per ondernemer zijn ongeveer $€ 500$. Door de integrale benadering dekt het Branchecodepad alle elementen van internal control af. De invulling hiervan wordt hierna per element besproken.

Control environment: Traditioneel staan kleine ondernemingen sceptisch tegenover systematische internal control. Door direct toezicht en veel besluitvorming op directieniveau beheerst de ondernemer zijn organisatie met management controls. Het besef van het belang van internal control moet dus meer gaan leven in de bedrijfscultuur van kleine ondernemingen. In de implementatiefase wordt de Branchecode branchebreed geïntroduceerd. De introductie van de Branchecode is gekoppeld aan training van branchegenoten. Deze codetrainingen zijn gericht op verdere bewustwording en motivering, het leren werken met de checklist bij de Branchecode, en het opstellen en implementeren van een Plan van Aanpak op basis van deze checklist. De codetraining wordt afgesloten met een trainingscertificaat. Er zijn reeds zorgverzekeraars en kruisverenigingen die het bezit van het trainingscertificaat verplicht stellen voor vergoedingen. Daarnaast zijn de Branchecodes opgenomen in de diverse vakopleidingen. Hierdoor wordt juist gedrag van meet af aan geïnternaliseerd.

Risico-analyse en internal control-maatregelen: Binnen de terminologie van het Branchecodepad worden deze

\begin{tabular}{|c|c|c|c|}
\hline Branche & $\begin{array}{l}\text { Aantal } \\
\text { bedrijven } \\
\text { in de } \\
\text { branche }\end{array}$ & $\begin{array}{l}\text { Verspreiding } \\
\text { Branchecode }\end{array}$ & $\begin{array}{l}\text { Introductiemaand } \\
\text { 1e versie van de } \\
\text { Branchecode }\end{array}$ \\
\hline $\begin{array}{l}\text { Glazeniers } \\
\text { (glas-in-lood) }\end{array}$ & 201 & 81 & februari 2000 \\
\hline Glazenwassers & 3.122 & 1.281 & januari 2000 \\
\hline Goud- \& zilversmeden & 1.606 & 406 & februari 2000 \\
\hline Kappers & 12.610 & 2.116 & november 1998 \\
\hline Keramiek \& aardewerk & 473 & 94 & februari 2000 \\
\hline Schoonheidsverzorging & 8.020 & 5.194 & december 1997 \\
\hline Slagers & 4.185 & 3.990 & februari 2001 \\
\hline Tandtechnici & 1.040 & 820 & maart 2001 \\
\hline Textielreiniging & 569 & 111 & september 1999 \\
\hline Uurwerkherstellers & 1.127 & 200 & november 2001 \\
\hline Voetverzorging & 6.478 & 5.439 & april 1997 \\
\hline
\end{tabular}

elementen aangeduid als Normalisatie en Implementatie. Op basis van de geldende wet- en regelgeving en stand der techniek worden normen vastgesteld. Vervolgens leveren documentenanalyse en bedrijfsbezoeken een basisset aan richtlijnen op. Deze basisset is afgeleid uit het doorsnee bedrijfsproces in het desbetreffende ambacht. Deze richtlijnen worden zoveel mogelijk in de vorm van werkinstructies geformuleerd. Dit maakt nadere vertaling naar het eigen bedrijf overbodig. De normen en richtlijnen zijn gegradeerd in drie sterktes, variërend van dwingend (legal practice) tot nastrevenswaardig (best practice). Tabel 2 geeft hiervan een illustratie.

De 'legal practice' sluit aan bij de coso-dimensie van 'voldoen aan wet- en regelgeving' en de 'good en best

\section{Tabel 2. Voorbeeld stringentieniveau Branchecodes}

\begin{tabular}{|c|c|c|c|}
\hline Gradatie & Status & $\begin{array}{l}\text { Voorbeeld persoonlijke } \\
\text { beschermingsmiddel }\end{array}$ & Voorbeeld hygiëne \\
\hline wet- \& regelgeving & $\mathbb{D} \mathbb{l}$ legal practice & $\begin{array}{l}\text { Er zijn voldoende op de risico's en het } \\
\text { gebruiksdoel afgestemde goed } \\
\text { passende persoonlijke beschermings- } \\
\text { middelen beschikbaar gesteld door } \\
\text { de werkgever. }\end{array}$ & $\begin{array}{l}\text { Wastafel, stromend (koud \& warm) } \\
\text { water. }\end{array}$ \\
\hline stand der techniek & good practice & $\begin{array}{l}\text { Inkoop harnasgordel: de harnasgordel } \\
\text { voldoet aan NEN-EN } 361 \text { en NEN-EN } 364 .\end{array}$ & $\begin{array}{l}\text { Wastafel voorzien van kraan met } \\
\text { elleboogbediening. }\end{array}$ \\
\hline optimale situatie & (;) best practice & $\begin{array}{l}\text { Gebruik een geïntegreerde } \\
\text { harnasgordel. }\end{array}$ & $\begin{array}{l}\text { Wastafel voorziening van kraan } \\
\text { met infraroodbediening }\end{array}$ \\
\hline
\end{tabular}


practice' sluiten aan op de optimalisering van effectiviteit en efficiency van de bedriifsprocessen.

Onder andere door deze gradaties vormt de Branchecode geen keurslijf. Er is voldoende ruimte voor de individuele ondernemer om zelf keuzes te maken. Hiermee wordt aangesloten op het 'baas in eigen bedrijf'-kenmerk. In het proces van Normalisatie en Implementatie speelt de betreffende brancheorganisatie een initiërende rol. Naast de werkgeversorganisaties worden in ieder geval de volgende stakeholders bij dit proces betrokken: werknemersorganisaties, ondernemers, leveranciers, het opleidingsveld en handhavingsinstanties. Deze stakeholders worden uitgenodigd zitting te nemen in de normalisatiewerkgroep. In overleg met deze werkgroep worden de richtlijnen gevalideerd op juistheid, relevantie voor de branche, technische toepasbaarheid en financiële haalbaarheid. Richtlijnen dienen ook aan het 'smart'-principe te voldoen (Waszink, 1991). Dit betekent dat richtlijnen specifiek, meetbaar, acceptabel, realistisch en tijdsgebonden zijn. Het gaat hier om een iteratief proces, dat afhankelijk van de complexiteit per zorggebied minimaal drie maanden per branche in beslag neemt. Na het validatieproces wordt de Branchecode door de sociale partners in de branche vastgesteld. Het normalisatieproces koerst op consensus tussen genoemde partijen. Verder ziet het HBA door werkgroepsamenstelling toe op onafhankelijkheid in het normalisatieproces.

Met de checklist voert de ondernemer een algehele risico-inventarisatie en -evaluatie in het bedrijf uit. De resultaten hiervan dienen als basis voor een verbeterplan. Het Plan van Aanpak zoals opgesteld binnen het Branchecodepad dwingt tot prioritering en cyclische evaluatie. Ter ondersteuning is er het trainingstraject. Het proces dat de ondernemer met de Branchecode doorloopt, volgt de door Shewhurst ontwikkelde verbetercyclus, bekend als de Demingcirkel 'Plan-DoCheck-Act' (Deming, 1986). Deze cyclus wordt regelmatig, maar ten minste eenmaal per jaar, doorlopen.

Informatie \& Communicatie: Doordat kleine ondernemingen door de platte organisatiestructuur doorgaans weinig delegatie kennen, ligt de nadruk bij informatie \& communicatie op het contact met de 'buitenwereld'. De Branchecode per bedrijfstak is vervat in een handzaam boekje, met daarbij de betreffende checklist. De administratieve belasting bij Branchecodes is relatief laag. Een eenvoudig in te vullen checklist en het daarop gebaseerde Plan van Aanpak van enkele A4-tjes is alles. Vergeleken met bijvoorbeeld de ISO-verplichting om een handboek met alle bijbehorende procedures en formulieren op te stellen, is de extra administratieve belasting van een
Branchecodepad zeer beperkt.

Het toepassen van de Branchecode biedt de ondernemer een eenduidig communicatiemiddel richting uiteenlopende stakeholders. Ondernemers die het hele Branchecodepad implementeren, beschikken over een onafhankelijk bewijsstuk van beheersing van het interne bedrijfsproces en van een gezonde bedrijfsvoering. Hiermee kan de ondernemer doelmatig en efficiënt communiceren met banken, handhavers, consumenten, potentiële werknemers, en bij onderhandelingen bij toelevering in het kader van het voldoen aan de effectiviteitseisen van deze stakeholders. De ondernemers besparen op de kosten van reguliere en incidentele externe informatievoorziening. Een dergelijk graadmeter van effectiviteiteisen is tevens een graadmeter voor de inspanningen op continuïteit van de onderneming.

Monitoring: Wat betreft de borging van de internal control kan een onderscheid worden gemaakt tussen enerzijds de adequaatheid van de richtlijnen rond de maatregelen, en anderzijds de naleving hiervan. Aangezien de problematiek van internal control rond arbo en milieu juist ligt in de snelle verandering van de omgeving, is het essentieel dat de richtlijnen van de Branchecodes up-to-date blijven. Het is in het ambachtelijke kleinbedrijf vaak op brancheniveau dat voortdurende verbeteringen worden gesignaleerd en in gang gezet. Onderhoud en uitbreiding van richtlijnen in opeenvolgende versies van de Branchecode vanuit het HBA en de brancheorganisaties bespaart het individuele bedrijf dus de nodige ontwikkelingsen zoekkosten. In 2000 is de 'Code van de Voetverzorger' herzien. Hierbij bleek dat ongeveer zestig procent van de richtlijnen moest worden aangepast. Dit illustreert de besparing die kan worden bereikt door deze informatievergaring te centraliseren. Deze aanpassingen zijn voor het merendeel het gevolg van voortschrijdend gefundeerd inzicht door actuele ontwikkelingen. Een voorbeeld hiervan is de legionellaproblematiek. In drie branches vroeg deze om onmiddellijke actie, namelijk in de kappersbranche, voetverzorging en schoonheidsverzorging. De drie branches tellen tezamen zo'n 26.000 ondernemingen. Ook regelgeving die binnen die tijdsperiode is bekrachtigd, zorgde voor aanpassing van normen in enkele Branchecodes. Bij andere branches biedt weten regelgeving geen afdoende antwoord op branchespecifieke vraagstukken. In dergelijke gevallen neemt het HBA in overleg met de relevante stakeholders het initiatief tot nader onderzoek dat als input dient voor wet- en regelgeving, branchenormen en handhavingsrichtlijnen. Recente voorbeelden hiervan zijn: 
- De blootstelling aan lood in de glazeniersbranche. Dit vraagstuk werd door TNO Arbeid opgenomen in een onderzoek ten behoeve van het ministerie van Sociale Zaken en Werkgelegenheid.

- De ergonomische belasting bij het werken op ladders in de glazenwassersbranche. Ook op dit terrein is een onderzoek door TNO uitgevoerd.

- Eerder werd in de glazenwassersbranche een onderzoek verricht naar alternatieven voor houten ladders en de mogelijke (samenhangende) bedrijfseconomische en arbotechnische aspecten.

- De wettelijke instructies aangaande tilbelasting voldoen niet bij het installeren van rolluiken, markiezen en zonwering. Het HBA liet hiervoor onderzoek verrichten om tot normstelling te komen.

\section{Certificering}

Wat betreft de toetsing van naleving bevat het Branchecodepad een certificeringsfase. Deze fase is nog niet geïmplementeerd, maar ligt wel op de tekentafel. Met het implementeren van certificering is bewust gewacht. Het Branchecodecertificaat zal als een objectief signaal ofwel waarborg van risicobeheersing naar diverse stakeholders toe fungeren. Om toegevoegde waarde te hebben, is het echter noodzakelijk dat er ook bij deze stakeholders vraag is naar assurance omtrent risicobeheersing. Immers, certificering brengt extra kosten met zich mee en wanneer het certificaat slechts ingelijst op kantoor hangt, heeft het nauwelijks toegevoegde waarde. Men moet niet certificeren om het certificeren alleen. De toegevoegde waarde van Branchecodecertificering ten opzichte van derde partijen wordt door het HBA aangeduid als het 'civiele effect' van certificering. Inmiddels dringt het bestaan van de Branchecode door bij diverse stakeholders. Voorbeelden hiervan zijn de Keuringsdienst van Waren en de Arbeidsinspectie. Deze toezichthouders staan positief tegenover de Branchecode, en hebben aangegeven dat zij in beginsel het bezit van een Branchecodecertificaat zullen beschouwen als een bewijs van naleving van hun voorschriften. Ook is het denkbaar dat in gerechtelijke procedures, bijvoorbeeld in verband met bedrijfsongevallen of milieuvervuiling, het aantoonbaar toepassen van de Branchecode een pleitgrond ter verdediging is. Met certificering zal dus pas worden gestart wanneer dit civiele effect opweegt tegen de extra kosten. Dit zal op zijn vroegst in het voorjaar van 2003 zijn.

De insteek van zo'n certificeringsproces kan op verschillende wijzen worden vormgegeven. Men kan aansluiting zoeken bij de principes van ISO-certificering. Daarbij dient men dan wel rekening te houden met de verschillen tussen ISO-certificering en Branchecode. Met name zal uitgebreide vastlegging zoals dat wel voorkomt bij ISO-certificering moeten worden vermeden.

Vanuit de accountancy zou de invalshoek van assurance services kunnen worden gevolgd. In het Elliottrapport worden diverse terreinen buiten de jaarrekening genoemd waar de accountant met zijn algemene vaardigheid van controleren een bepaalde mate van zekerheid kan geven (zie onder andere www.aicpa. org). Een van die terreinen is de risicoanalyse (risk assessment). Een van de assurance services in het kader van risk assessment is 'evaluation of an entity's systems for identifying and limiting risks', dus in dit geval de naleving van de Branchecode. Volgens het Elliott-rapport zou de accountant bij uitstek geschikt zijn om dit type assurance te verlenen, omdat de accountant traditioneel al met een brede blik naar de bedrijfsvoering kijkt, en bekend is met allerlei regelgevingen. Er zou slechts in enige mate bijscholing nodig zijn. Naar onze mening is het Elliott-rapport hierin wellicht iets te optimistisch, aangezien accountants bij regelgeving op niet-financieel gebied vaak steunen op andere deskundigen. Maar juist bij Branchecode is dergelijke informatie dus al verzameld. Ook voor de accountant is de Branchecode dus een belangrijke informatiebron voor de te toetsen normen.

Het Elliott-rapport signaleert terecht dat een standaard moet worden ontwikkeld voor zulke certificeringsopdrachten. Weliswaar is het internal control-systeem genormaliseerd in Branchecodes, maar voor de certificering zal eenduidig moeten worden bepaald wat een dergelijke certificering in concreto betekent: wat verklaart de accountant eigenlijk? Bij de traditionele accountantsverklaring bij de jaarrekening bestaat al een expectation gap. Dit zal zich bij een dergelijke nieuwe service nog sterker voordoen. Aangezien Branchecode drie gradaties van normalisatie kent, zal duidelijk moeten zijn op welk niveau gecertificeerd is. Uiteraard zal de gradatie 'legal practice' volledig moeten worden nageleefd. Anderzijds is het niet noodzakelijk dat alle ondernemingen volledig voldoen aan de 'best practice'. De scheidslijn zal dus ergens liggen binnen de gradatie 'good practice'.

Een andere insteek van assurance in het kader van Branchecode zou die van Policy Compliance kunnen zijn: 'The CPA provides assurance with respect to specific company policies, such as codes of conduct, human resource policies, (...), environmental matters. The policies might be based on internal control concerns, laws, or regulations. Or, they might be based on the company's philosophy or as a preventative approach to potential risks'. Hierbij gaat het dus niet om het toetsen van het 
internal control-systeem, maar om de uitkomsten: is er daadwerkelijk voldaan aan wet- en regelgeving? Vooralsnog wordt deze benadering niet gekozen, mede omdat hier al een taak ligt voor bestaande toezichthouders, zoals de Keuringsdienst van Waren en de Arbeidsinspectie.

\section{Branchecode en accountant}

Vanwege de aversie tegen externe consultants die vaak bestaat in het amkb, is het Branchecodepad zodanig ontworpen dat de ondernemer het in principe zelfstandig kan toepassen. Dit is bijvoorbeeld een verschil met ABIB, waarover Scheffe en Flapper opmerken dat de ervaring leert dat gebruikers van ABIB over goede kennis en vaardigheden dienen te beschikken op het gebied van organisatiekunde of bedrijfsdiagnose. Voor Branchecode is de rol van de accountant duidelijk anders. Uit HBA-onderzoek blijkt dat de accountant een van de weinige adviseurs is die wel regelmatig door MKB-ondernemers wordt geraadpleegd. Vanwege de geringe omvang is er meestal geen sprake van accountantscontrole, maar verleent de accountant administratieve hulp of stelt de jaarrekening of belastingaangifte samen. In dit kader kan er dan ook geadviseerd worden op onder meer bedrijfseconomisch gebied. Branchecode is ook voor de accountant een handzaam startpunt om zijn branchekennis up-to-date te houden. Omdat sommige richtlijnen samenhangen met investeringen in bedrijfsmiddelen, ligt hier een adviserende rol voor de accountant. De accountant kan de verschillende alternatieven die de Branchecode aanbiedt doorrekenen op basis van de specifieke omstandigheden van de onderneming.

In een later stadium, wanneer naleving van Branchecodes wordt gecertificeerd, ligt het voor de hand dat het de accountant is die deze assurance service zal aanbieden. Weliswaar is de controle van kleine ondernemingen van oudsher moeilijk door een gebrek aan geformaliseerde functiescheidingen, maar de tendens is dat audit standards meer ruimte gaan bieden om gebruik te maken van management controls, zoals dat al voorkomt in Leidraad 5 (NoVAA, 1994), en de recentelijk verschenen IFAC Practice Statement 1005 (NIVRA, 2000).

\section{Mogelijkheden van het Branchecodepad buiten het ambachtelijk mkb}

Belangrijk kenmerk van het Branchecodepad is dat het een algemeen concept is, dat in allerlei sectoren kan worden toegepast. De voorbeelden uit tabel 1 zijn dus niet incidentele 'success stories' van individuele pogingen om internal control in te voeren in een bepaalde branche, maar de resultante van een gezamenlijke onderliggende structurele aanpak. Deze aanpak is niet beperkt tot ambachtelijke ondernemingen, maar kan in principe door elke bedrijfstak met een eigen branchevereniging of bedrijfschap worden gevolgd. De belangrijkste randvoorwaarden zijn: er is voldoende standaardisatie van het bedrijfsproces; er is een centraal orgaan - bijvoorbeeld een bedrijf-

- schap of branchevereniging - die bereid is om de

- coördinerende functie op zich te nemen; dit centraal orgaan moet de menskracht en deskundigheid hebben om de ontwikkelingen in wet- en

- regelgeving tijdig te signaleren; er moeten voldoende partijen binnen de branche bereid zijn om in gezamenlijk overleg de normalisatie - en implementatie vast te stellen en te onderhouden; bij voorkeur dient er een vakopleiding te bestaan waarin de vastgestelde best practices branchebreed in - de bedrijfstak kunnen worden gefundeerd.

Met een aanpak zoals die van het Branchecodepad gebaseerd op de contingentie- en stakeholderstheorie, kunnen veel bedrijfstakken met kleine ondernemingen de risicobeheersing op efficiënte wijze verbeteren en hiertoe gerichte advies van de accountant inwinnen.

\section{Literatuur}

Committee of Sponsoring Organizations of the Treadway Commission (COSO), (1994), Internal control, integrated framework, American Institute of Certified Public Accountants, New York.

Deming, W., (1986), Out of the crisis: quality, productivity and competitive position,

Cambridge, Cambridge University Press.

Hooi, S.I.U., (1998), Integrale Kwaliteitszorg en Codes van het Ambacht, Voorburg: HBA

Instituut Nederlandse Kwaliteit (INK), www.ink.n

Lantinga, E.J., G. Roorda, (1998), Codes als strategie van branches, Voorburg: HBA.

Maijoor, S.J., (1997), Corporate governance, internal control en het midden- en kleinbedrijf, in: Accountant Adviseur, vol. 31, nr. 1/2, pp.11-15

Nederlands Instituut van Registeraccountants (NIVRA), (2000), Richtlijnen voor de Accountantscontrole.

Nederlandse Orde van Accountants-Administratieconsulenten (NoVAA), (1994), Controleprogramma voor Kleine en Middelgrote Ondernemingen, Kluwer.

Scheffe, J.,G. Flapper, (2001) ABIB, instrument voor interne beheersing, in: De Accountant, vol.107, nr.8, pp.422-425 .

Waszink, A.C., (1991), Kwaliteitszorg en certificatie, Samson Bedrijfsinformatie.
}

Noot

1 Ontleend aan de website van het INK, www.ink.nl 